\section{7. 筋からの複合的な求心性入力が発汗反応に及ぼす影響}

$\bigcirc$ 天野 達郎 ${ }^{1} 、$ 一瀬 真志 ${ }^{2}$ 、三輪 樹生 ${ }^{1}$ 、井上 芳光 ${ }^{3} 、$ 西保 岳 ${ }^{4}$ 近藤 徳彦 (1 $^{1}$ 神戸大学大学院 人間発達環境学研 究科、年明治大学、 ${ }^{3}$ 大阪国際大学、筑波大学)

【背景および目的】運動時におけるヒトの発汗反応は深部体温 などの温度情報のほか，温度に依存しない非温熱性要因の影響 も受けて調節されている。非温熱性要因のうち筋代謝受容器お よび筋機械受容器活動は筋からの求心性入力として発汗反応を 引き起こし，また，循環系には前者が血圧を，後者が心拍数お よび血圧を増加させる．動的な運動時などには両受容器が同時 に活動して発汗反応を調節していると考えられるものの, 両受 容器の複合的な求心性入力がどのようにその反応を調節してい るかは明らかではない，本研究では筋代謝受容器活動時に異な る筋において筋機械受容器が活動した場合の発汗反応を検討す る。【方法】被験者は健康な若年男性14名㧍よび女性 2 名で，環 境温 $35^{\circ} \mathrm{C}$ および相対湿度 $50 \%$ の環境下において，半仰臥位・長 座姿勢で1分間の静的掌握運動 㵊大握力（MVC）の35および 50\%\} 後に3分間の前腕部阻血を行い，阻血開始後2分目から両 足首を受動的に背屈する下肢ストレッチを30秒間実施した。ま た，静的掌握運動後の休息時に同ストレッチによる単独影響を みるため，30秒間の下肢ストレッチを行った。 ストレッチの程 度は被験者が痛みを感じる直前の角度とした。【結果および考 察】下肢ストレッチ時の心拍数はすべての条件で変化しなかっ たが，平均血圧および発汗量はすべての条件でストレッチ前よ り有意に増大した。また，運動後阻血中のストレッチによる平 均血圧および発汗量の増大程度は，35\%および50\%MVCともス トレッチ単独変化と運動後阻血時の変化の和と差がなかった。 これらの結果は，筋代謝受容器活動中に異なる筋で筋機械受容 器が活動した場合には血圧および発汗反応は付加的に増加する ことを示している.さららに, その増加程度は筋代謝受容器の活 動レベルに影響されないと考えられる。

Keywords : 筋機械受容器 熱放散反応 非温熱性要因

\section{9. 食事内容の違いが暑熱下運動時における呼吸循環反応に 及ぼす影響}

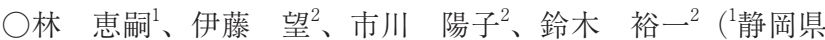
立大学 短期大学部、2静岡県立大学大学院 生活健康科学研 究科)

【背景】食事内容の違いにより，食事誘発性熱産生の程度が異 なったり，食後の糖質や脂質の燃焼割合が変化したりする。食 事内容によって，食後の代謝が異なることが予想されるが，食 事内容の違いが暑熱下運動時における呼吸循環反応に及ぼす影 響は不明である。【目的】食事内容の違いが暑熱下運動時にお ける呼吸循環反応にどのような影響を及ぼすかを検討すること を目的とした。【方法】被験者は健康な男性10名 (24 2 歳) で, 実験時には水循環スーツを着用し， $50 \% \mathrm{~V}_{2 \text { peak }}$ 強度の自転車運 動を25〜60分間行った。測定は高糖質食摂取 (CHO食) 条件 と高たんぱく質食摂取（P食）条件で行った。食事は1日の基 準值の25～30\%を満たすエネルギー量とし，それに見合うよう にたんぱく質，脂質，糖質の調整をした。【結果】実験で摂取 した食事のエネルギー量は，CHO食で $752 \pm 84 \mathrm{kcal} ， \mathrm{P}$ 食で707 $\pm 74 \mathrm{kcal}$ であり，条件間で差はなかった。また，CHO食条件 でたんぱく質，脂質，糖質の比率が5:18:78であり，P食条件で 21:23:57であった，運動前の安静時において，食道温，心拍数， 換気量, 酸素摂取量, 二酸化炭素排出量等に条件間で差はみら れなかった。運動中は，一回換気量や呼吸交換比が $\mathrm{CHO}$ 食条 件でP食条件よりも高い值を示したが，食道温，心拍数，換気 量等には条件間で差はみられなかった。深部体温上昇に対する 換気㝋進反応や皮膚血管拡張反応においても，条件間で差はみ られなかった。【結論】本実験で摂取した食事内容の違いによっ ては, 食事誘発性熱産生には差は生じなかったと考えられるが, 食事内容が変化することで，食後の呼吸反応に違いがみられる ことが示唆された

Keywords：深部体温＼cjkstart換気方進 皮膚血管拡張
418. バスケットボールプレー中における発汗量および尿 $\mathrm{pH}$ 変 化が味覚閾値に及ぼす影響

○藤原 綾佳 ${ }^{1}$ 祝原 豊 $^{2} 、$ 杉山 康司 ${ }^{2}$ (1静岡大学 教育学 研究科、2静岡大学)

【目的】スポーツ活動中、体内から失われた水分と消費した栄 養を補給するためにスポーツドリンクがよく用いられている。 しかし、スポーツ選手は市販のスポーツドリンクを濃いと感じ、 薄めて飲む傾向がある。これは脱水または高強度運動により、 味覚閯值が変化すると考えられる。しかし、運動が味覚変化に 影響を及ぼすかどうか、十分な知見がまだ得られていない。そ こで、本研究の目的はバスケットボール鍛錬者を被験者とし、 脱水を伴う運動前後の味覚閾值変化について検討することとし た。【方法】バスケットボール部に所属する女子大学生14名を 被験者とした。20mシャトルランを含む2時間のバスケットボー ル練習を主運動とし、主運動前後に甘味、塩味および酸味にお ける味覚閾值テスト、唾液 $\mathrm{pH}$ 検査、尿検査 $(\mathrm{pH}$ 、タンパク質、 潜血)、体重を測定した。主運動中は、心拍数、各練習項目の OMNIスケールを測定した。【結果】HRからみた主運動時の運 動強度は76.6 $8.7 \% \dot{\mathrm{VO}}_{2} \max$ であった。尿 $\mathrm{pH}$ 運動前後で7.1 1.8 から $5.8 \pm 0.7$ と有意に低下し $(\mathrm{p}<0.01)$ 、尿たんぱく質は運動 前後で29.6 $\pm 63.9 \mathrm{mg} / \mathrm{dL}$ から $89.6 \pm 76.1 \mathrm{mg} / \mathrm{dL}$ と有意に増加した $(\mathrm{p}<0.05)$ 。潜血は陰性であった。また、発汗量および体重減 少率は $1073 \pm 310 \mathrm{ml} 、 1.99 \pm 0.55 \%$ であり、軽度脱水を伴う高強 度運動時において、味覚闇值は甘味のみ明らかな低下を示した $(\mathrm{p}<0.05)$ 。他の味覚について、運動前後の味覚閾值テストの 結果から、䦨值低下群と非低下群に分類したところ、酸味では 低下群において有意な尿 $\mathrm{pH}$ 低下を示し $(\mathrm{p}<0.05)$ 、塩味では、 発汗量が有意に多かった $(\mathrm{p}<0.05)$ 。【考察】本研究の結果から、 軽度脱水を伴う高強度運動は、甘味味覚閾值を低下させると考 えられた。また、甘味のみならず、発汗量が増えると、酸味お よび塩味においても味覚閾值低下がおきると示唆された。

Keywords：味覚閾值 高強度運動 発汗量

\section{0. 頸部冷却が温暖環境下における認知機能及び持久的運動 能力に及ぼす影響}

$\bigcirc$ 長谷川 博、志水 嶺輝 $^{2}\left({ }^{1}\right.$ 広島大学大学院 総合科学研究 科、丢広島大学 総合科学部)

【目的】頸部冷却が温暖環境下における認知機能及び持久的運 動能力に及ぼす影響について検討した。【方法】健康な8名の男 性が室温 $30^{\circ} \mathrm{C}$, 湿度 $80 \%$ に設定された実験室で最大負荷強度の $65 \%$ の自転車運動を疲労困䣏に至るまで2回行った。実験条件 は，運動中にネッククーラーを装着するCOOL条件，装着しな いCONTROL条件とした。認知機能の指標として，ストループ カラーワードテスト及び実行機能テストを運動時に 10 分間隔及 び疲労困䣏時に測定した。【結果】運動継続時間はCONTROL 条件と比較してCOOL条件で有意に延長した (COOL: 50.2 06.3 分, CON: $43.9 \pm 4.1$ 分, $\mathrm{p}<0.05)$ 。COOL条件に打ける運動開始 後40分のストループテストの回答時間はCONTROL条件と比 べ短縮傾向を示し，また疲労困巽時において回答時間は有意に 短縮した。実行機能テストではCOOL条件の回答時間が運動開 始後40分と疲労困謈時で有意に短縮された。直腸温及び心拍数 は運動中上昇したが，同時刻の比較では条件間で有意な差がな かった。頸部冷却により運動開始後35分及び40分の主観的運動 強度, 運動開始後15分から40分の温熱感覚が軽減された。結論】 温暖環境下における運動中の頸部冷却は直腸温などの生理的指 標を変化させないが, 主観的運動強度や温熱感覚を軽減するこ とで認知機能及び持久的運動能力を向上させることが明らかと なった。

Keywords：体温上昇 認知機能 長時間運動 


\section{1. 安静時暑熱暴露による暑熱順化が暑熱下運動時の換気反} 応に及ぼす影響

○过 文 1 、本田 靖 1 、藤井 直人 ${ }^{2}$ 近藤 徳彦 ${ }^{3}$ 西保 岳 ${ }^{1}$

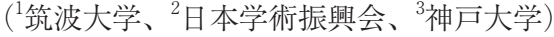

【背景】暑熱環境下で一定負荷持続的運動を行い媣部体温が上 昇すると、代謝性ではない換気量の増加反応が見られるが（温 熱性過換気)、その特性は十分に明らかではない。温熱負荷を 繰り返し加えることで暑熱順化とよばれる生理的適応が起こ り、暑熱下運動時の発汗や皮膚血管拡張反応の改善が起こるが、 換気充進反応に及ぼす暑熱順化の影響はほとんど明らかではな い。近年我々は、深部体温上昇時の換気充進反応において、換 気量増加の深部体温闇值が約 $37^{\circ} \mathrm{C}$ で見られ、それ以上の温度で は深部体温上昇に対して換気量が直線的に増加することを明ら かにした（Tsuji et al. Am J Physiol 2012）。この換気立進の䦭 值および閾值以降の深部体温上昇に対する換気感受性（深部体 温と換気量の回帰直線の傾き）が暑熱順化によってどのような 影響を受けるのかは不明である。【目的】暑熱順化が暑熱下一 定負荷運動時の換気兇進反応に及ぼす影響を検討する。【方法】 健常男性9名を対象とし、10日間連続の安静時暑熱暴露（室温 $45^{\circ} \mathrm{C}$, 湿度 $50 \%$ の環境下で2時間の安静暴露; 深部体温は $38.5^{\circ} \mathrm{C}$ で維持）の前後で、暑熱下運動負荷テスト（室温 $37^{\circ} \mathrm{C}$, 湿度 50\%の環境下で50\% $\mathrm{V}_{2}$ peak負荷の自転車運動を50〜 120分間 行う）を実施した。【結果】10日間の安静時暑熱暴露による暑 熱順化によって、先行研究と同様に、安静時深部体温は低下し $\left(0.3^{\circ} \mathrm{C}\right)$ 、さらに運動時における発汗開始の深部体温閾值は低 下し (36.4 vs. $\left.36.0^{\circ} \mathrm{C}\right) 、$ 深部体温上昇に対する発汗の感受性は 増大した $\left(0.9\right.$ vs. $\left.1.3 \mathrm{mg} / \mathrm{cm}^{2} / \mathrm{min} /{ }^{\circ} \mathrm{C}\right)$ 。換気六進の深部体温 間值は暑熱順化後に低下し $\left(37.2\right.$ vs. $\left.36.9^{\circ} \mathrm{C}\right)$ 、深部体温上昇に 対する換気感受性は増大した $\left(10.5\right.$ vs. $\left.14.5 \mathrm{~L} / \mathrm{min} /{ }^{\circ} \mathrm{C}\right)$ 【結論】 本結果より、暑熱下中強度一定負荷運動時に拈ける深部体温上 昇に対する換気圥進反応は暑熱順化によって増大することが示 唆された。

Keywords：温熱性過換気 暑熱順化 体温調節反応

\section{3. 若年および高齢者におけるアクアビクスの基本動作にお ける運動強度とその決定因子}

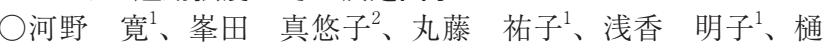
口 満 $^{1}$ ( ${ }^{1}$ 早稲田大学 スポーツ科学学術院、 ${ }^{2}$ 早稲田大学 ス ポーツ科学研究科)

【目的】水中運動は、肥満者や整形外科的疾患者にとって関節 に負担をかけずに行える運動様式の一つである。しかしながら、 その運動強度は、現場の指導者の感覚によって決定される現 状がある。そこで本研究は、アクアビクスの4つの基本動作に おける運動強度の決定因子を明らかにすることを目的とした。 【方法】様々な体格を有する38名の若年者 $(21 \pm 2$ 歳、 $172 \pm 6$

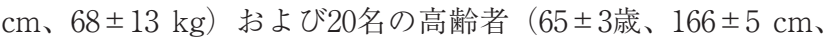
$63 \pm 9 \mathrm{~kg}$ ）の男性が実験に参加した。全ての被験者は、陸上に おいて体組成、体表面積、下腿断面積および最大酸素摂取量

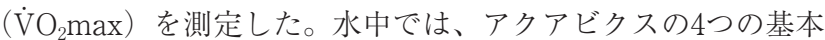
動作であるシザース、ジャンピング、ロッキング、キッキング を無作為に5分間実施し、最後の1分間に酸素摂取量を測定し た。【結果】アクアビクスの基本動作の運動強度は、若年者お

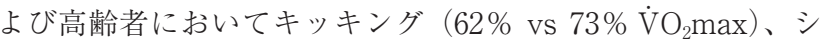

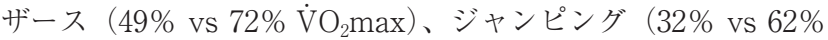
$\left.\dot{\mathrm{V}} \mathrm{O}_{2} \max \right) 、$ 、ッング (31\% vs 51\% $\left.\dot{\mathrm{VO}}_{2} \max \right)$ の順に高かく、 若年者よりも高齢者の方が高かった。アクアビクスの基本動作 に打ける運動強度の決定因子としては、若年者では、主に心肺 体力、体表面積および下腿断面積が、高齢者では心肺体力が独 立して関係していた。【結論】本研究は、若年者と比較して高 齢者の方がアクアビクス中の運動強度が高いこと、また若年者 と高齢者ではアクアビクス中の運動強度の決定因子に違いがあ ることを明らかにした。

Keywords：アクアビクス 運動強度 加齢

\section{2．現代日本人の環境適応能力に与える運動習慣の影響}

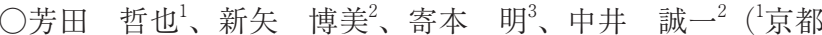
工芸繊維大学大学院 基盤科学系 数理自然部門、2京都女子 大学、滋賀県立大学)

【目的】本研究では温熱負荷時の体温調節反応や安静時のエネ ルギー代謝量（安静時代謝量）を季節毎に測定し，ヒトの暑 熱・寒冷耐性に関係する環境適応能力を男女間，季節間，運動 有無間で比較した.【方法】被験者は運動習慣の有る群（男10名, 女10名）と無い群（男11名, 女12名）を対象とし, 実験は春, 夏, 秋, 冬の年間 4 回, 女性は卵胞早期に実施した. 被験者は長袖シャ ツと半ズボンを着用し環境温度 $25^{\circ} \mathrm{C}$ の実験室で 30 分間以上の安 静の後, 呼気ガスを7分間採取して安静時代謝量を測定した。 その後, 遠赤外線スチーム足浴器の温度を $44^{\circ} \mathrm{C}$ に設定し, 60 分 間下肢加熱を行った。分析は前腕の皮膚血流量（SkBF）及び 発汗量 (SR) が上昇する時の食道温 (Tes)の值をTes閯值とし, 安静時におけるTesの最低值とTes閾值との差をTes上昇闇值 ( $\Delta \mathrm{Tes})$ とした.【結果】運動群における1週間の運動内容は男 性群が1回に3時間程度の運動を週3回，女性群が1回90分の運動 を週2回行っていた。下肢加熱により SkBF，SRが上昇するTes 閾值は運動有無間，男女間および季節間で有意差は認められな かったが，運動有の男女が運動無の男女よりも夏に下がり冬に 上がる傾向がみられた。 SkBFの $\Delta$ Tesは女性非運動群以外で は夏は冬に比べて有意に低く, SRの $\Delta$ Tesでは男性運動群以外 で夏は秋または冬に比較して有意に低值を示した。また男性群 の早朝空腹時安静時代謝量は冬に上昇するが，女性群には顕著 な変動が認められなかった【考察】本研究の結果より, 男女 間および運動有無間で暑熱適応反応の年間変動に違いが認めら れた。また本研究の女性群は男性群よりも体脂肪が平均 $10 \%$ 程 度多かったことから，冬季の安静時代謝量上昇に与える体脂肪 の影響が考えられる.したがって, 現代日本人の環境適応能力 は運動習慣や性差によって異なることが示唆された。

Keywords：暑熱適応 寒冷適応 安静時代謝量

\section{4. 夏季の生活環境の違いが暑熱耐性に与える影響}

○田井村 明博 1 管原 正志、松波 勝、塚本 絵里菜 3 、 山崎 真生 $^{3}$ ( ${ }^{1}$ 長崎大学 水産・環境科学総合研究科、 ${ }^{2}$ 西日本 短期大学、 ${ }^{3}$ 長崎大学環境科学部)

【背景】エアーコンディショナー（エアコン）の普及率が年々 増加している。快適な環境を求めエアコンに頼る結果、動物が 本来持っている体温調節反応の能力を失ってしまうとの報告 もある。【目的】本研究は暑熱耐性を測定し、その結果に夏季 のエアコン使用頻度の違いがどの程度影響するのかを検討し た。【方法】暑熱耐性に関するアンケート調査をもとに、夏季 にエアコンを使用した群（使用群：3名）と夏季にエアコンを ほとんど使用しなかった群（不使用群：8名）を被験者とした。 実験は被験者の同意のもと行われ、温湿度環境を一定 $\left(26^{\circ} \mathrm{C} 、\right.$ $50 \%$ RH）にした人工気象室内で行った。被験者は人工気象室 で15分間の安静状態を保った後、 $43^{\circ} \mathrm{C}$ の温水に両下腿部を 30 分 間浸漬させた。浸漬後は再び15分間の安静状態を保ち実験終了 とした。測定項目 (1) 皮膚温：平均皮膚温、腹部皮膚温、(2) 核心温: 口腔温、(3) 心拍数、(4) 発汗量: 実験前後の体重の差、(5) 汗の成分分析 : $\mathrm{Na}^{+}$值、 $\mathrm{K}^{+}$值、 $\mathrm{Cl}^{-}$值、(6) 全身、下腿部の温度 感覚・温度快適性。【結果】エアコン使用群に扣いて、核心温、 平均皮膚温の上昇が小さく、発汗量も少く、汗中の Na濃度も 低かった。考察】暑熱環境に適応すると汗中の $\mathrm{Na}^{+}$濃度が低く、 暑熱負荷中に皮膚温が比較的高い傾向にあることが報告されて いる。エアコン使用頻度の差が夏季中の暑熱暴露時間の違いの 要因の一つとなると考えられ、これらのことから夏季のエアコ ン使用頻度の違いは暑熱耐性すなわち、暑熱環境への適応に影 響を与えていると考えられる。【結論】夏季のエアコンの使用 頻度により暑熱耐性に影響することが示唆された。今回の実験 では主に夏季のエアコンの使用頻度に重点を置きアンケート調 査を行ったが、今後は暑熱耐性に関連するその他の要因を含め、 より詳細に検討する必要があると思われる。

Keywords：生活環境 暑熱耐性 汗成分 
425. 高体温が上肢運動時の活動筋および非活動筋の筋疲労に 及ぼす影響

○大谷 秀憲 ${ }^{1}$ 、賀屋 光晴 2 、辻田 純三 $^{3}$ ( ${ }^{1}$ 姫路獨協大学 医療保健学部、 ${ }^{2}$ 兵庫医療大学 共通教育センター、 ${ }^{3}$ 兵庫医科 大学 健康スポーツ科学)

【背景】運動時には深部体温上昇により中枢性および末梢性疲 労の両方が助長されることが知られている。この反応は高体温 誘発性疲労と呼ばれているが、先行研究では自転車エルゴメー ターなどの下肢の筋を活動筋とする運動を用いた報告が大多数 であり、上肢の筋を活動筋とする運動を用いた報告は非常に少 ない。【目的】本研究は、顎下浸水により深部体温を受動的に 上昇させた後、上肢エルゴメーター運動を用いることにより、 高体温が上肢運動時の活動筋（上腕二頭筋）と非活動筋（外側 広筋）の筋疲労に及ぼす影響について検討することを目的とし た。【方法】男性被験者 8 名はCybexを用いた等速性筋力テス 卜（MT）を行った後、浴槽での30分間の顎下浸水により深部 体温を変化させた。浸水後は 2 回目のMTを行った後、直ちに 60\% $\dot{\mathrm{VO}}_{2} \max$ 強度の上肢エルゴメーター運動をオールアウトに 到達するまで実施した。オールアウト後は 3 回目のMTを行っ た。MTは肘関節屈伸および膝関節屈伸とし、各測定時に最大 筋力と筋持久力を測定した。顎下浸水時の水温は $40^{\circ} \mathrm{C}$ と $36^{\circ} \mathrm{C}$ の 2 条件とした。【結果】浸水終了時の直腸温は $40^{\circ} \mathrm{C}$ 群が $38.1 \pm$ $0.3^{\circ} \mathrm{C} 、 36^{\circ} \mathrm{C}$ 群が $37.1 \pm 0.3^{\circ} \mathrm{C}$ であった。上肢エルゴメーターの 運動継続時間は $40^{\circ} \mathrm{C}$ 群 $\left(41 \pm 13\right.$ 分) が $36^{\circ} \mathrm{C}$ 群 $(52 \pm 12$ 分) に比 べ有意の低值を示した $(\mathrm{P}<0.01)$ 。運動時の直腸温、平均皮 膚温、心拍数、皮膚血管コンダクタンス、糖質および脂質酸化 量は条件間に差が認められなかった。MTおよび積分筋電図は、 浸水後 (2 回目) の上腕二頭筋の最大筋力測定で $40^{\circ} \mathrm{C}$ 群が $36^{\circ} \mathrm{C}$ 群よりも有意の低值を示した $(\mathrm{P}<0.05)$ 。【結論】上肢運動時 には高体温により持久性パフォーマンスと上腕二頭筋の最大筋 力が有意に低下することが観察された。

Keywords : 体温 筋疲労 持久性パフォーマンス

\section{7．仰臥位浸水が心臟足首血管指数に及ぼす影響}

$\bigcirc$ 斎藤 辰哉 1 、西村 正広 $^{2}$ 、高原 皓全 ${ }^{3}$ 、高木 祐介 ${ }^{1}$ 、村

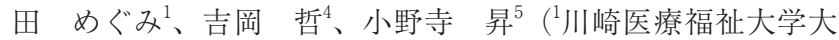
学院、 ${ }^{2}$ 鳥取大学、 ${ }^{3}$ 人間総合科学大学、 ${ }^{4}$ 香川大学、 ${ }^{5} 川$ 崎医療 福祉大学)

【背景】上腕-足首間脈波伝播速度 (baPWV) および拡張期血圧 (DBP) は，陸上仰臥位姿勢より水温 $30^{\circ} \mathrm{C}$ 仰臥位浸水時に高值 を示す. baPWVおよび心臓足首血管指数 (CAVI) は, 動脈ス ティフネスの指標である。baPWVは，血圧の影響を強く受け るが，CAVIは，血圧の影響を受けにくい，このことから，浸 水時の動脈スティフネスの指標としてCAVIが血圧の影響を排 除した指標になると推測する。【目的】仰卧位浸水がCAVIに 及ぼす影響を明らかにすることとした。【方法】被験者は健康 な成人男性6名であった。測定条件は，陸上条件（L条件）お よび水温 $30^{\circ} \mathrm{C}$ 仰臥位浸水条件（W条件）とした。 W条件は，顔 面以外の全身仰臥位浸水とした。室温は， $25.0^{\circ} \mathrm{C}$ であった。測 定項目は，心拍数，血圧およびCAVIとした，L条件は，10分 間の陸上仰臥位安静後に測定を実施した。W条件は，5分間の 陸上仰臥位安静後および5分間の仰卧位浸水後に測定を実施し た。【結果と考察】W条件のDBPおよびCAVIは，L条件に比較 して有意に高值を示した $(\mathrm{p}<0.05)$ 。 心拍数は，条件間に有意 な差は観察されなかった。中立温よりも低い温度で水中浸漬 を行った場合，ふるえによる熱産生増加执よび皮膚血管の収 縮による熱放散の抑制が起こる，W条件のDBPは，L条件に比 較して有意に高值を示したことから，浸水時のCAVIの増加に は，皮膚血管収縮による末梢血管抵抗の増大が関与している 可能性が考えられた。【結論】W条件のCAVIは，L条件に比較 して，高值を示すことが明らかになった。水温 $30^{\circ} \mathrm{C}$ 浸水時の baPWVおよびCAVIが陸上と比較して高值を示したことから, 水温 $30^{\circ} \mathrm{C}$ 浸水時の動脈スティフネスは, 増加することが明らか になった

Keywords : 浸水 CAVI 血圧
426. 高体温時ヘッドアップティルト時の右心房容量変化が皮 膚血管コンダクタンスに及ぼす影響

○小 雄 ${ }^{1}$ 、上條 義一郎 ${ }^{1}$ 、池川 茂樹 ${ }^{1}$ 、増木 静江 ${ }^{1}$ 、森 田 淳美、能勢 博 $^{1}$ ( ${ }^{1}$ 信州大医学系研究科 スポーツ医科学) 【背景】ヒト高体温時に低血液量は皮膚血管拡張を抑制するが 発汗反応を抑制しない。この結果は、心房の脱伸展が圧反射性 に皮膚血管拡張を抑制するが発汗反応には影響しないことを示 唆する。しかし、急性姿勢変換時の右心房容量変化と皮膚血管 拡張反応・発汗反応の関係を検討した研究はない。【目的】高 体温時に水平臥位から $30^{\circ}$ ヘッドアップティルト (HUT) を行っ た時の右心房容量の減少は、皮膚血管拡張反応を減少させるが 発汗反応は減弱させない、という仮説を検証すること。【方法】 健常な男性12名 (22-42歳)に環流スーツを着用させ、まず $34^{\circ} \mathrm{C}$ の水を流しながら水平臥位の後HUTを行い、その際の右心房 容量 (超音波ドップラー法)、平均動脈圧 (MAP; 上腕・前脛骨 動脈; コロトコフ法)、心拍数 $(\mathrm{ECG})$ 、皮膚血流量 $(\mathrm{SkBF}$; 胸 · 足背部; レーザー・ドップラー法) と発汗速度 (SR; 足背部; カプ セル換気法)を測定した。次に $47^{\circ} \mathrm{C}$ の水を流して食道温を $0.7^{\circ} \mathrm{C}$ 上昇させた後に同様の測定を行った。胸・足背部皮膚血管コン ダクタンス $(\mathrm{CVC})$ はSkBFをそれぞれ上腕・前脛骨動脈に扮け るMAPで除して求めた。【結果】平・高体温時共に、HUTで は臥位に比べ、右心房容量が減少し、心拍数と上腕・前脛骨 動脈におけるMAPが上昇し、足背部CVCが低下した（すべて $\mathrm{P}<0.01)$ 。特に、高体温時では胸部C VCも低下した $(\mathrm{P}<0.02)$ 。 一方、高体温時のSRは、HUTでは臥位に比べ、充進する傾向 を認めた $(\mathrm{P}=0.09)$ 。結論】HUTによる右心房容量の減少は圧 反射性に皮膚血管拡張反応を減少させるが発汗反応は減弱させ ない。

Keywords：圧反射性皮膚血流調節 右心房容積 皮膚交感神経 活動

428. 環境温度がエアロビックダンスによる味覚感受性の変化 に及ぼす影響

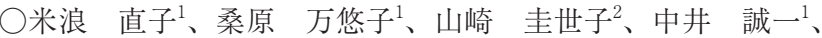

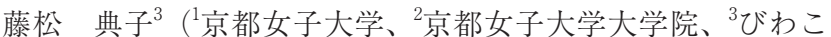
成蹊スポーツ大学

【目的】我々は、先行研究においてランニングによる運動負荷 が味覚感受性に及ぼす影響とその要因について報告してきた。 本研究では、冬季から夏季にかけて同一強度のエアロビック ダンスを行い、運動時の環境温度（WBGT：Wet Bulb Globe Temperature、湿球黒球温度）および発汗率が味覚感受性に及 ぼす影響について検討した。【方法】被験者は一般女子大学生 延べ104名とした。冬季から夏季にかけての3シーズンに計14回、 同一強度（110～120bpm）でのエアロビックダンスをそれぞれ 60分間実施した。WBGT、発汗率、口渇感の測定、味覚検査、 嗜好検査を行った。味覚検査は甘味、酸味、塩味について全口 腔法により認知閾值を測定した。嗜好検査では、市販の糖・電 解質含有飲料を使用して、Visual Analog Scale (VAS) 法に て「飲料の好ましさ」「濃度の感じ方」に関する検査を行った。 口渴感についてもVAS法にて検査を行った。運動時の環境温 度によりWBGT $15^{\circ} \mathrm{C}$ 未満のL群 $(\mathrm{n}=32) 、 15 \sim 21^{\circ} \mathrm{C}$ 未満のM群 $(\mathrm{n}=26) 、 21^{\circ} \mathrm{C}$ 以上のH群 $(\mathrm{n}=46)$ の3群に分け、それぞれ比 較検討した。【結果】WBGTと発汗率には有意な正の相関がみ られ $(\mathrm{p}<0.01)$ 、発汗率を3群で比較するとH群で有意に高い值 を示した $(\mathrm{p}<0.01)$ 。味覚検査では、運動前に比べて運動後に、 L群で酸味闇值のみ有意に低下し、M、H群では、甘味と酸味

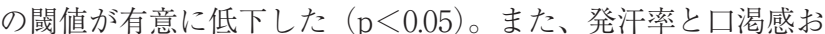
よび「飲料の好ましさ」の得点にはそれぞれ正の相関、「飲料 の好ましさ」と「濃度の感じ方」の得点には有意な負の相関が 見られた $(\mathrm{p}<0.05)$ 。以上のことから、運動中のWBGTや発汗 率が高い条件では、運動後に甘味、酸味の味覚闇值が低下し、 味覚が敏感になることが示唆された。さらに、市販飲料の味の 感じ方や嗜好性にも違いが見られた。

Keywords：味覚閾值 嗜好性 発汗率 


\section{53次南極観測夏隊員の南極帯在における生理的応答}

○山内 潤一郎 ${ }^{1} 、 川$ 茂雄 ${ }^{2}$ 衣笠 竜太 ${ }^{3}$ 、宮崎 充功 ${ }^{4}$ 木 田 圭亮 ${ }^{5}$ 森田 憲輝 ${ }^{6}$ 瀧澤 一騎 ${ }^{7} 、 山 口 太-8$ 、橋本 健 志 ${ }^{9}$ 、藤田 聡 $^{10}$ 、桑原 悠一 ${ }^{11}$ 、橋本 信子 ${ }^{11}$ 、内田 直 $^{12}$ 、伊 村 智1 ( ${ }^{1}$ TMU/FIfSS、 ${ }^{2}$ 東京大学/FIfSS、3神奈川大学/FIfSS、 ${ }^{4}$ 北海道医療大学/FIfSS、 ${ }^{5}$ 聖マリアンナ医科大学/FIfSS、 ${ }^{6}$ 北 海道教育大学、 ${ }^{7}$ 北海道大学、酪農学園大学、 ${ }^{9}$ 立命館大学/ FIfSS、 ${ }^{10}$ 立命館大学、 ${ }^{11}$ 国立極地研究所、 ${ }^{12}$ 早稲田大学/FIfSS) [背景］南極は日照時間の変化が大きく、一年を通して低温な 環境にあるためヒト生体にとっても極めて特殊な環境といえ る。このような環境下でのヒト生体の生理学的な応答に関する 報告はほとんどなく、以前として未開拓の領域である。南極滞 在がどのような生体応答を生じるかについて調査することは、 極地で研究に従事する研究員などの健康管理のためにも重要な 課題と考えられる。[目的］本研究では、53次南極観測夏隊員 の南極滞在における生理的応答について検討することを目的と した。[方法］南極観測隊員を対象として、南極滞在前後に一 般測定項目 (体重、体組成、血圧、脈拍、安静時代謝)を測定す るともに、唾液、血液を採取して分析をした。これらの測定に は十分な説明の後に同意を取れた隊員のみを対象とした。南極 観測中は医療班による隊員の健康診断や体調モニタリンも実施 した。南極で 3 ケ月間キャンプ生活を送るセールロンダーネ隊 については隊員自身に体重、体調、食事などを記録してもらっ た。[結果と考察］夏隊員の一般測定項目については大きな変 化はみられなかった。3名のセールロンダーネ隊の血液結果に ついて3名とも同じ変化を示した項目は、ノルアドレナリン、 ドーパミン、IL-1RA (以上増加)、一方、グレリン不活性型 (減 少)だった。今後より詳細に南極環境がヒト生体内の生理的反 応について、生理学的、生化学的な実験手法を用いて体系的に 検討していく必要がある。

Keywords：寒冷 代謝 極地

\section{1．運動時体温調節に及ぼす水分摄取の効果}

$\bigcirc$ 大貫 義人 ${ }^{1}\left({ }^{1}\right.$ 山形大学 地域教育文化学部 文化創造学 科 スポーツ文化コース)

[はじめに］温熱環境下における運動中の熱産生量の増加は、 運動能力の低下や暑熱障害の要因となるため、運動中の水分攝 取は非常に重要である。そこで本研究では60分間の連続運動時 に水分摂取 1 回を設け、個人体重の $0.1 \% 、 0.3 \% 、 0.5 \%$ に相当す る水分量を規定し、その飲水前後の水分摂取による体温調節機 能に及ぼす影響について検討した。[実験方法］被験者は健康 な男子学生 10 名とした。室温 $30^{\circ} \mathrm{C}$ 、相対湿度 $50 \%$ 、風速 $0.1 \mathrm{~m} /$ sec.の条件下で、運動強度は $600 \mathrm{kpm} / \mathrm{min}$ の仕事量として、自 転車エルゴメーターを用いて60分間の運動を行った。A.飲水な し、B:体重の $0.1 \% 、 \mathrm{C}$ :体重の $0.3 \% 、 \mathrm{D}$ :体重の $0.5 \% の$ 飲水を運動 開始30分後に行う4パターンの飲水条件において鼓膜温、平均 皮膚温、体重減少率、発汗量、心拍数について測定した。[結 果と考察]鼓膜温の上昇度より、B-D間において 45 48分でDが 低い有意傾向を示した。また、60分運動終了時から60分運動終 了後10分目 (70 80分)での鼓膜温の上昇度では、76 79分の間 において A-D間でDが低い有意傾向を示した。平均皮膚温の上 昇度より、飲水を行わなかった Aが飲水を行った $\mathrm{B} 、 \mathrm{C} 、 \mathrm{D} よ り$ も運動開始30分目から飲水後30分目の60分運動終了時(40 70 分)で常時高い傾向を示している。特に55分 70分の間で顕著 に現れている。体重減少率では水分摂取を行わなかった場合、 被験者 3 で1.2\% 1.5\%の体重減少が見られ、体重の $0.1 \%$ 相当量 の飲水時でも被験者 3 名で1.0\% 1.3\%の減少が見られた。よっ て長時間運動を継続する場合、少なくとも体重の $0.1 \%$ 以上の飲 水量が必要であることが推察される。[まとめ]温熱環境下にお ける長時間の運動を継続する際には体重の $0.3 \%$ から $0.5 \%$ 相当量 の水分を確保することで体温調節機能や循環調節機能の維持に 効果が得られる可能性があると示唆された。

Keywords：水分摂取 温熱環境 体温調節

\section{0. 高体温時の姿勢変化が温度感覚に及ぼす影響}

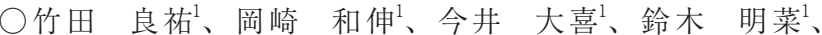
Naghavi Nooshin ${ }^{1}$ 、松村 新也 ${ }^{2}$ 、宮側 敏明 ${ }^{1}$ ( $^{1}$ 大阪市立大 院 医学研究科 運動環境生理学、 ${ }^{2}$ 大阪体育大院 スポーツ科 学研究科)

【背景】皮膚温および深部温の上昇は，温度感覚として体温調 節中枢に入力され，それに対して体温調節応答は立進する。一 方，高体温時の仰臥位から椅座位への姿勢変化による中心血液 量の低下は，自律性体温調節応答を減弱させることから，体温 調節中枢やその遠心路に影響すると考えられるが，姿勢変化の 温度感覚に及ぼす影響は不明である。【目的】高体温時の姿勢 変化が温度感覚に及ぼす影響を検討する。【方法】健常な男性 15 名を対象に，環境温 $28^{\circ} \mathrm{C}$, 相対湿度 $40 \%$ の工気候室内にお いて, 平常体温時 (食道温: $36.6 \pm 0.2^{\circ} \mathrm{C}$ ) および下肢温浴 $\left(42^{\circ} \mathrm{C}\right.$ ) による高体温時（食道温： $37.3 \pm 0.1^{\circ} \mathrm{C}$ ）に仰臥位および椅座位 の2試行をランダムに実施した。各試行において，前腕部・胸 部の皮膚温に加え, 温度感覚の指標として, 前腕部・胸部の皮 膚の温度感覚（温覚および冷覚： $\pm 0.1^{\circ} \mathrm{C} /$ 秒）閾值，および, 全身の温度感覚（VAS法）を測定した。また，食道温，血圧， 前腕部・胸部の皮膚血管コンダクタンス $(\mathrm{CVC})$ および局所 発汗量（SR）を連続測定した。【結果】両温度条件において， 仰臥位に比べ椅座位では脈圧が有意に低下した。平常体温時に 比べ高体温時では，全身の温度感覚は両試行において有意に上 昇したが，前腕部・胸部の皮膚の冷覚閾值は椅座位においての み有意に低下 (鈍化) した。また，皮膚の冷覚閾值では2元配 置分散分析法において, 体温（平常体温vs.高体温）と姿勢（仰 臥位vs.椅座位) の交互作用が有意傾向 (胸部: $\mathrm{P}=0.08$, 前腕部： $\mathrm{P}<0.05 ） に あ り ，$ 高体温による冷覚閾值の鈍化の程度は，仰 臥位に比べ椅座位で大きかった。両温度条件において，仰卧位 に比べ椅座位では, 全身の温度感覚は有意に上昇した。【結論】 姿勢変化によって，高体温時の温度感覚は変化する。

Keywords：温度感覚 高体温，姿勢变化

432. 水中と陸上における座位安静時の尿量および尿意感の比較

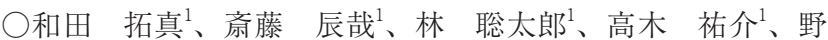
瀬 由佳 ${ }^{2}$ 、小野寺 昇 $^{3}{ }^{1}$ 川崎医療福祉大学大学院、姿安田女 子大学、衫崎医療福祉大学大学院)

【背景】浸水時に生体は、水の物理的特性の影響を受け陸上と は異なる生理的反応を示す。浸水時に、利尿作用が促進する。【目 的】本研究は、座位に扔ける陸上と水中の尿量、尿意感、主観 的温度感覚指標および心拍数を比較し、浸水時の利尿作用につ いて検討した。【方法】対象者は、健康な成人男性 9 名（年齢： $20.9 \pm 0.9$ 歳、身長: $167.7 \pm 4.6 \mathrm{~cm}$ 、体重 : $68.8 \pm 6.6 \mathrm{~kg}$ 、体 脂肪率： $14.2 \pm 3.9 \%$ )であった。測定条件は、陸上座位安静 条件 ( C条件) および鎖骨位までの浸水を行う水中座位安静条 件 ( $\mathrm{W}$ 条件) とした。両条件ともに、室内温水プール（水温： $30.2 \pm 0.3{ }^{\circ} \mathrm{C}$ 、室温 : $28.3 \pm 0.3{ }^{\circ} \mathrm{C}$ 、湿度 : $\left.56.7 \pm 4.4 \%\right) に$ て測定した。測定項目は、尿量、尿意感、主観的温度感覚指標 および心拍数 ( HR ) とした。C条件は、120分間の陸上座位安 静とした。W条件は、30分の陸上座位安静後、浸水し、30分の 浸水座位安静をとった。退水後、体表面部の水分を拭き取り、 回復期としてプールサイドで60分間の座位安静を保った。尿 意感および尿量は、30分毎に測定した。【結果】退水直後、回 復30分時および回復60分時のW条件の尿量および尿意感は、C 条件と比較して有意に高值を示した $(\mathrm{p}<0.05)$ 。W条件浸水時、 回復5分から30分までの主観的温度感覚指標は、C条件と比較し て有意に高值を示し、寒いと感じた $(p<0.05)$ 。W条件浸水時、 回復10分時および回復15分時のHRは、C条件と比較して有意に 低值を示した $(\mathrm{p}<0.05)$ 。これらのことは、浸水が利尿作用を 促進させたことを示唆する。【結論】1）浸水によって尿量およ び尿意感が増加する、2）回復時の時間経過に伴い、尿量が減 少する、3）回復時における尿量の減少は、主観的温度感覚指 標と連動する、ことが明らかになった。

Keywords：尿量 尿意感 水中環境 


\section{3. 加圧空気チェンバー (HBA) 入室が運動選手の血液流動性} におよぼす影響

$\bigcirc$ 添嶋 裕嗣 ${ }^{1}$ 長島 未央子 ${ }^{1}$ 齊藤 和人 $^{1}$ ( $^{1}$ 鹿屋体育大学 スポーツ生命科学系)

【緒言】著者らは，運動選手を対象に1.3気圧HBAに60分間入室 させ，酸化ストレス，抗酸化力および血液流動性の測定を行っ た結果，酸化ストレスに関係なく全血細孔通過時間（FT）が 短縮することを報告した(日本臨床高気圧潜水医学会誌6: 27, 2009）。ヘパリンは血小板の凝集能には影響しないため血小板 凝集能と赤血球の変形能の変化が流動性に反映される。本研究 ではさらに血液流動性変化の詳細について検討を行った。【方 法】男子大学生44名をHBAに60分間入室させ、その前後で末 梢血、FT、酸化ストレス度拈よび抗酸化力としてd-ROMと BAPをFRS4で測定した。FTはMC-FAN（HR300）を用いて 測定した。FTを通過流量 $10 \mu$ l毎に $100 \mu$ 1まで測定し、最初の $10 \mu$ に要した時間と $100 \mu$ のの流出に要した実際の時間とその 理論的時間の差から算出される面積を閉塞度 (単位: Fbv) と し、10 $\mu$ 1毎に求められる流動時間が理論的時間より $10 \%$ の遅 延が生じた時点を変曲点とし検討した。また流速量 $(100 \mu 1)$ と 流速時間 (100msec)より得られる面積よりBlood Vulnerability Index（BVI）を求めた。【結果】HBA入室により修正BAP/ d-ROM比に有意な変化は見られなかったが, 赤血球,白血球, $\mathrm{Ht}, \mathrm{Hb}$ ，血小板数は有意に減少した(すべて $\mathrm{p}<0.001)$ 。また、

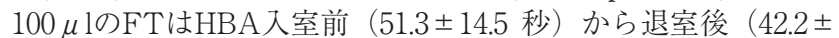
6.2 秒 $)$ へと有意に短縮した $(\mathrm{p}<0.0001)$ 。通過流量 $10 \mu 1$ 毎に HBA入室前後のFTを検討した結果， $10 \mu 1$ の通過時間からすべ ての時点で有意に短縮し, 閉塞度は $448 \pm 519$ から $160 \pm 122$ に有意に減少し, 変曲点は $44 \pm 2$ から $60 \pm 3$ へと有意に延長 した $(\mathrm{p}<0.01)$ ，BVIは $2416 \pm 591$ が $2010 \pm 227$ へと有意に減 少した $(\mathrm{p}<0.0001)$ 。結論】HBA入室によるFTの短縮は、血 液希釈による赤血球変形能の改善や血小板凝集抑制によると推 察された。

Keywords : 加圧空気チェンバー 運動選手 血液流動性

\section{5. 低圧環境下における自由泳が高齢2型糖尿病モデルラット のインスリン抵抗性に及ぼす影響}

$\bigcirc$ 柳楽 晃 ${ }^{1}$ 黑部 一道 ${ }^{2}$ 黄 忠 ${ }^{3}$ 芝野 広一 ${ }^{1}$ 、山中 大祐 ${ }^{1}$ 、 西脇 雅人 ${ }^{4}$ 、齊藤 和人 ${ }^{5}$ 與谷 謙吾 ${ }^{5} 、$ 荻田 $太^{5}\left({ }^{1}\right.$ 鹿屋体 育大学大学院、熊本県立大学、 ${ }^{3}$ 国立スポーツ科学センター、

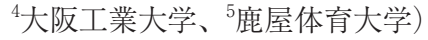

【背景】低圧環境下における運動トレーニングは、常圧環境下 のそれよりインスリン抵抗性を効果的に改善させることが報告 されている。しかしながら、高齢者を対象としても、同様の効 果が得られるかは不明である。【目的】本研究は、低圧環境下 に拈ける自由泳が高齢2型糖尿病モデルラットのインスリン抵 抗性に及ぼす影響について検討することを目的とした。【方法】 被検体は 100 週齢の自然発症 2 型糖尿病モデルラットとし、常圧 環境下 (常圧群: $3 匹)$ 、または海抜 $2500 \mathrm{~m}$ 相当の低圧環境下（低 圧群：5匹）において1日1回30分間の自由泳を連続5日行わせ、 2日間の休息を挟み、更に連続5日行わせた。トレーニング前、 5回、10回のトレーニング後に空腹時血糖值・インスリン濃度、 HOMA指数、インスリン耐性試験時の血糖值、および血糖值 アンダーカーブ面積が測定された。また、10回のトレーニング 後の測定が終了した翌日に解剖が行われ、前肢滑車上筋・肝臓 のグリコーゲン濃度、前肢滑車上筋におけるGLUT4濃度が定 量された。【結果】常圧群はトレーニング期間を通して全ての 指標において有意な変化はみられなかった。一方、低圧群で は10回のトレーニング後、空腹時血糖值、およびインスリン耐 性試験時の血糖值アンダーカーブ面積が有意に低下した $(\mathrm{P}<$ 0.05)。尚、前肢滑車上筋・肝臓のグリコーゲン濃度、および前 肢滑車上筋におけるGLUT4濃度は、両群間に有意な差は認め られなかった。【結論】以上の結果より、低圧環境下における 自由泳は、高齢の 2 型糖尿病モデルラットにおいてもインスリ ン抵抗性を改善させること、またその効果が表れるまでには少 なくとも10回程度のトレーニングを要することが示唆された。

Keywords: 低圧環境 インスリン抵抗性 2型糖尿病モデル ラット

\section{4．低酸素環境における有酸素性運動が常酸素環境での回復} 期の代謝応答に及ぼす影響

○黒部一道、黄 忠、柳楽 晃、芝野 広一 3 、山中 大祐 ${ }^{3} 、$ 山本 正嘉、荻田 $太^{4}$ (熊本県立大学、年国立スポーツ科学 センター、尔鹿屋体育大学大学院、 ${ }^{4}$ 鹿屋体育大学)

【背景】低酸素への曝露、およびそこでの運動は、糖代謝を卉 進させることが報告されている。しかしながら、低酸素環境で の運動後、回復期を常酸素環境で過ごしても糖代謝が光進され たままかは不明である。【目的】低酸素環境における有酸素性 運動が常酸素環境での回復期の代謝応答に及ぼす影響について 検討することを目的とした。【方法】健康な成人男性8名（23士 1歳）に50\% $\mathrm{VO}_{2} \max$ 強度に扔ける自転車運動を30分間行わせ、 運動後90分間の安静回復を保った。本実験は、低酸素環境 $\left(\mathrm{FiO}_{2}\right.$ = 15.5\%）に運動前30分から運動後30分まで90分間曝露し、続 いて運動後90分までの60分間、常酸素環境で安静を保つH条件 と、実験を通して常酸素のみに曝露したN条件に分けた。運動 強度は各条件における相対的同一強度とした。呼吸・血液指標 を運動前30分 (安静時)、運動直前 (安静曝露時)、運動時、運 動後30分、60分、90分に測定した。【結果】H条件に扔ける動 脈血酸素飽和度は、安静時と比較し曝露開始から運動後30分 まで有意に低下し $(\mathrm{P}<0.01) 、 そ の$ 間の值はN条件と比較して も有意に低かった $(\mathrm{P}<0.01)$ 。運動時の酸素摂取量、血中乳酸 濃度は、H条件より N条件の方が有意に高かったが（P<0.05）、 安静、安静曝露時、回復期では両条件間に有意な差はなかった。 また、 $\mathrm{H}$ 条件の安静時に扔ける呼吸交換比は、安静曝露後、運 動時に有意に上昇し $(\mathrm{P}<0.01)$ 、運動後60分では安静レベルま で戻ったものの、その值はN条件より有意に高い值であった（P <0.01）。グルコース抢よびインスリンは、条件間で有意な差 はみられなかった。結論】以上の結果より、低酸素環境に㧈 ける運動は、常酸素環境に戻った回復期でも、通常より高い糖 代謝が維持されることが示唆された。

Keywords : 低酸素 有酸素性運動 糖代謝

\section{6。低酸素下における低強度レジスタンス運動がホルモン応} 答に及ぼす影響

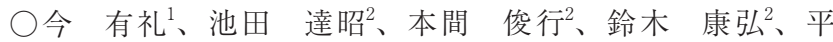
野 裕- ${ }^{2}$ ( ${ }^{1}$ 日本学術振興会特別研究員、 ${ }^{2}$ 国立スポーツ科学セ ンター)

【背景】血流制限を伴うレジスタンス運動は効果的に筋肥大㧍 よび筋力増加を引き起こすことが報告されている。このような 筋の適応には，血流制限による局所的な低酸素化が筋内代謝産 物の蓄積をもたらし，成長ホルモンの分泌を促進させるためで あると推測されている。【目的】本研究では, 低酸素環境下に おける低強度レジスタンス運動がホルモン応答に及ぼす影響に ついて検討することを目的とした。【方法】健常成人男性8名を 対象とし, 常酸素環境下と低酸素環境下で低強度のレジスタン 久運動を実施した。低酸素条件では，低酸素ガス発生装置を用 いて酸素濃度13.0\%のガスを吸入させた。レジスタンス運動に は, ベンチプレス抢よびレッグプレス（負荷強度：50\%1RM， セット数：5セット，セット間・種目間休息：1分）を用いた。 運動前後に採血を行った。測定項目は, 血中乳酸濃度, 成長木 ルモン，抢よびノルエピネフリンとした。【結果】血中乳酸濃 度は, 運動前と比較し両環境下の運動直後から有意に増加した が, 低酸素レジスタンス運動のほうが常酸素レジスタンス運動 よりも有意に高值を示した $(\mathrm{p}<0.05)$ 。成長ホルモンは，低酸 素レジスタンス運動後のみ運動前と比較し有意な増加が認めら れた $(\mathrm{p}<0.05)$.ノルエピネフリンは, 運動前と比較し両環境 下の運動直後に有意な増加が認められた（ $\mathrm{p}<0.05 ）$ が，群間 に打ける有意差は認められなかった。 [考察]先行研究に扔いて, 乳酸などの代謝産物の蓄積は成長ホルモンの分泌を刺激するこ とが報告されている。従って，低酸素レジスタンス運動後にお けるより大きな代謝産物（乳酸）の蓄積が成長ホルモンの分泌 増大を引き起こした可能性がある。【結論】低酸素環境下にお ける低強度レジスタンス運動は, 常酸素環境下と比較して成長 ホルモンの分泌を増加させる可能性が示唆された

Keywords : 成長ホルモン 低酸素環境 乳酸 
437. 低圧環境下で行う運動のタイプが心血管応答および動脈 スティフネスに及ぼす影響

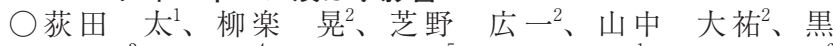
部 一道 ${ }^{3}$ 、黄 忠、西脇 雅人 ${ }^{5}$ 、與谷 謙吾 ${ }^{1} 、$ 田巻 弘之 $^{6}$

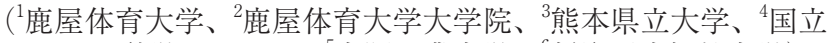
スポーツ科学センター、学大阪工業大学、6 新潟医療福祉大学) 【背景】我々は、低圧環境下に打けるトレーニングが、常圧環 境下におけるそれより、血压、動脈スティフネスの低下、1 回拍出量、心拍出量の増加といった心血管応答の改善を、よ り効果的に、より短期間で誘発することを報告してきた。【目 的】本研究では、低圧環境下で行う運動のタイプが、心血管応 答掞よび動脈スティフネスに及ぼす影響について明らかにする

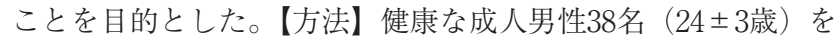
被検者とし、常圧環境 (常圧群)、または海抜 $2500 \mathrm{~m}$ 相当の低 圧環境下 (低圧群) に扔いて、水中運動、あるいは自転車エル ゴメータ運動を行う4群に分けた。被検者は、予め求められた $50 \% \dot{\mathrm{V}} \mathrm{O}_{2} \max$ 相当の強度において、1回30分間、連続5日間の運 動トレーニングを行った。尚、低圧群は、1 回のトレーニング セッションにつき約 2 時間、低圧環境に曝露された。トレーニ ング前後に、最大下強度運動時の心拍数、1 回拍出量、心拍出 量（超音波ドップラー法）、血圧、および上腕一足首脈波伝播 速度（baPWV）、血流依存性血管拡張反応（\% FMD）を測定 し、比較した。【結果】トレーニング後、常圧群では、水中運 動群、自転車エルゴメー夕運動群のどちらも、全ての指標にお いて有意な変化は認められなかった。また、低圧群においても、 自転車エルゴメー夕運動群では有意な変化は認められなかった が、水中運動群では、最大下運動中の1回拍出量、心拍出量の 有意な増大、および最高血圧、平均血圧の有意な低下が観察さ れた $(\mathrm{P}<0.05)$ 。さらに、baPWVの有意な低下、\% FMDの有 意な増加も認められた $(\mathrm{P}<0.05)$ 。【結論】以上の結果より、低 圧環境下における運動トレーニングは、5日間という短期間で も動脈スティフネスや血圧の低下をともなう 1 回拍出量、心拍 出量の増大といった心血管応答の改善をもたらすものの、その 変化は運動夕イプによって異なる可能性が示された。

Keywords：低圧低酸素環境 水中運動 自転車運動

\section{9. 低酸素環境下での運動時生理応答に対する短時間低酸素 曝露の効果の個人差}

$\bigcirc$ 岡根谷 真平 ${ }^{1} 、$ 福崎 千穂 ${ }^{1} 、 久$ 久保田 善彦 ${ }^{1} 、$ 前川 剛輝 ${ }^{2} 、$ 成田 和穂 ${ }^{3}$ 石井 直方 ${ }^{1}\left({ }^{1}\right.$ 東京大学大学院、 ${ }^{2}$ 日本女子体育 大学、 ${ }^{3}$ 日本体育大学)

【背景】我々の先行研究で、短時間 (60分間) 低酸素曝露の直 後に低酸素環境下での運動を行ったところ、常酸素曝露後に比 べて心拍数が低下し、運動強度の高いところでは換気量が低下 することが明らかになった。【目的】このような短時間低酸素 曝露の効果に個人差が認められるのかどうかについて検討する こと。【方法】健康な20代男性11名を被験者とし、事前に個人 の特性として、身長、体重、体脂肪率、除脂肪体重、肺機能、 血圧、 $\dot{V} \mathrm{O}_{2} \max$ 測定した。60分間の常圧低酸素室滞在（16.7\% $\left.\mathrm{O}_{2}\right)$ あるいは常圧常酸素室滞在後、低酸素ガス $\left(16.7 \% \mathrm{O}_{2}\right)$ を 吸引しながら自転車エルゴメータでの多段階運動負荷試験（各 段階3分間）を15分間行った。2つの試行は1週間の期間を空け、 滞在酸素濃度は被験者により順不同とした。運動負荷試験では 運動終了時の心拍数、動脈血酸素飽和度、換気量、血中乳酸濃 度を測定した。そして、常酸素曝露後（NE）の低酸素環境下 運動での值に対する低酸素曝露後 ( $\mathrm{HE})$ の值の比 ( $\mathrm{HE} / \mathrm{NE}$ ) を各指標について求め、それらと個人特性との間でピアソンの 相関係数を求めた。有意水準は $5 \%$ とした。【結果】 $\mathrm{VO}_{2} \max$ と 動脈血酸素飽和度のHE/NE間に有意な負の相関が認められた $(\mathrm{r}=-0.629, \mathrm{P}=0.038)$ 【結論】 $\dot{\mathrm{V}} \mathrm{O}_{2} \max$ は短時間低酸素曝露後 の低酸素環境下での運動時生理応答に対して影響を及ぼすこと が明らかとなった。

Keywords : 低酸素 最大酸素摂取量 動脈血酸素飽和度

\section{8． 陸上短距離選手を対象とした短期間低酸素合宿の効果} ○居石 真理絵 ${ }^{1} 、$ 本田 覀紀子 ${ }^{2}$ 、松林 武生 ${ }^{1}$ 高橋 恭平 ${ }^{3}$ 、 有光 玩磨 ${ }^{1}$ 、麻場 一德 ${ }^{4}$ 鈴木 康弘 ${ }^{1}$ ( ${ }^{1}$ 国立スポーツ科学 センター、 ${ }^{2}$ 中京大学、熊本高等専門学校、都留文科大学)

【背景】近年、低酸素環境を利用した宿泊とトレーニングは、 持久系種目だけでなくスプリント系種目の選手にも活用されて きているが、その効果や有効なトレーニング法については明ら かになっていない。また、実際の競技現場において、長期間の 合宿を実施することが困難な場合も多く、比較的短期間で効果 を得られる方法を検討することは重要と考えられる。【目的】 陸上短距離選手に対して6日間の低酸素宿泊とトレーニングを 実施し、その効果について検討すること。【方法】被験者は主 に400mを専門とする大学女子陸上選手7名とし、5泊6日の合宿 中に低酸素環境（14.4\%）での自転車エルゴメーターによるス プリントトレーニング（30秒間全力ペダリング5セット）を4回、 トレッドミルでのランニング30分間（5分間ごとに走速度を漸 増) と自転車エルゴメーター30分間 (定常負荷)の持久性トレー ニングを5回実施した。また、夜間は低酸素環境（16.4％）の 部屋に8時間以上滞在した。測定として、合宿前後にトレッド ミルを用いて、最大酸素摂取量 $\left(\dot{\mathrm{V}} \mathrm{O}_{2} \mathrm{max}\right)$ テストおよび最大 無酸素性ランニングテスト（MART）を実施した。なお、合 宿後の $\mathrm{VO}_{2} \max$ テスは合宿終了翌日に、MARTは7日後に実 施した。【結果】トレーニング前後の測定結果を比較したとこ ろ、トレーニング後の $\dot{\mathrm{V}} \mathrm{O}_{2} \max$ に有意な変化は認められなかっ たが、運動持続時間が有意に向上した。またMARTにおける 最大パワーは有意に向上し、各セット後の血中乳酸濃度が有意 に低下した。最高乳酸值の相対值として算出した最大下パワー が20\%、40\%、60\%で有意に向上した。【結論】陸上短距離選手 を対象とした6日間の低酸素合宿により、走効率および最大パ ワーが向上することが示唆された。

Keywords：低酸素 短期間 スプリント

\section{0．急性低酸素状態はStroop課題の成績を低下させる}

$\bigcirc$ 山田 諭基 ${ }^{1}$ 、赤堀 光哉 1 、西保 岳 ${ }^{1}$ 征矢 英昭 ${ }^{1}$ ( ${ }^{1}$ 筑波 大学 人間総合科学研究科)

【背景】登山の遭難や高地でのスポーツ競技時における注意・ 集中力の低下は, 中枢での機能の低下が起こっているかもし れない，高地下では，大気の酸素分圧低下による脳内低酸素 状態が招くため，脳神経活動の低下が示唆されている。 それ により低酸素状態は人の認知機能を低下させている可能性が 考えられる。登山やスポーツ現場の事故を未然に防ぐ上でも, 低酸素状態が認知機能の注意・集中に関連する実行機能に与 える影響を明らかにすることは重要であるが，いまだ検討さ れていない。【目的】本研究では，実行機能に及ぼす低酸素吸 入の効果を明らかにすることで，登山擬似モデルの作成を試 みた。【方法】健常な学生22名を被験者とし，20分間の低酸素 (11\%；高度 $5000 \mathrm{~m}$ 相当) 吸入の前後に認知課題 (Color Word Stroop Task: CWST) を行う低酸素条件と、低酸素の代わり に常酸素を吸入する常酸素条件の 2 条件を同一被験者に実施し た。吸入後のCWSTは，各酸素条件の空気吸入を継続させなが ら行った. CWSTは, NeutralとIncongruentから構成され、各 課題の反応時間 $(\mathrm{RT})$ とエラー率を評価した。さらに本研究で は，ストループ干渉（Incongruent-Neutral）の值を，実行機 能を反映する指標として統計解析に用いた。【結果】 Netural • Incongruent のRTとエラー率に対して, 実験（低酸素/常酸 素）と時間（Pre/Post）の 2 元配置分散分析を行ったところ, Netural ・ Incongruent のRTとエラー率で有意な交互作用が見 られた。 その後, 低酸素・常酸素条件に比べて, 低酸素条件 はNetural・Incongruent課題ともにRTを遅延させた。さらに, エラー率のNetural ・ Incongruentの值を上昇させた。同様の解 析をストループ干渉に行ったが差は認められなかった。【結論】 急性低酸素吸入は反応時間を遅延させた。これは, 低酸素下で 運動する場合には，実行機能が低下しうることを示唆する。 Keywords : 低酸素 認知機能 中枢性疲労 


\section{1. マイルドな高酸素ガス曝露によるラット海馬組織酸素分} 圧の変化とそのメカニズム

○吉里 秀雄、ゲゲン トンラガ、花井 淑晃 ${ }^{1} 、$ 吉村 篤司 ${ }^{1} 、$ 樋口 寧彦 1 、小畠 一輝 ${ }^{1}$ ( ${ }^{1}$ 名古屋工業大学大学院)

【背景】高酸素環境では曝露される酸素濃度や時間の違いによっ て、脳神経系に様々な変化が引き起こされるが、そのメカニズ ムついては不明な点が多い。また様々な高酸素環境下にある脳 組織酸素分圧の変化を継時的に捉えた報告もほとんど無い。そ こで今回我々は、高酸素環境下におけるラットの海馬組織酸素 分圧の変化およびそのメカニズムについて報告する。【目的】 高酸素曝露によって誘導される海馬組織酸素分圧上昇とそのメ カニズムに活性酸素が関与しているかについて検討した。【方 法】8週齢のSDラット (雄)を使用し、脳海馬部位にクラーク型 酸素電極（ユニークメディカル社製）を挿入可能にするために ガイドカニューレの留置手術を行った。術後 2 日、測定チャン バー内にてAir及び $30 \%$ O 2 （N 2 バランス）ガスを20分間づ つ交互に2回還流し、リアルタイムで海馬の組織酸素分圧を測 定した。【結果】高酸素ガス曝露に対し海馬組織酸素分圧が約 120\%上昇した。また高酸素ガス曝露15分前に活性酸素除去剂 を投与すると $30 \%$ 酸素ガスに誘導される海馬組織酸素分圧の上 昇が強く抑制された。【結論】マイルドな高酸素ガス曝露によ り海馬組織酸素分圧が上昇することが認められた。この組織酸 素分圧の上昇は、血液溶解酸素の増加では説明することが出来 ず、海馬神経活動の活性化による局所脳血流の上昇に起因する ものと考えられる。また、この組織酸素分圧の上昇には活性酸 素が関与することが示唆された。

Keywords : 高酸素 組織酸素分圧 海馬

\section{3. 高校男子卓球選手の競技特性 一視機能と反応時間一}

村上 博巳 1 、山本 武司 ${ }^{2}$ 、山岡 憲二 ${ }^{3}$ 増田 洋 4 田 阪 登紀夫 ${ }^{5}$ 足利 善男 ${ }^{1}$ 、田中 信雄 ${ }^{1}$ ( ${ }^{1}$ 京都産業大学 文化 学部、 ${ }^{2}$ 京都華頂大学、 ${ }^{3}$ 京都文教短期大学、 ${ }^{4}$ 京都嵯峨芸術大学、 ${ }^{5}$ 同志社大学)

【目的】卓球競技は瞬時に多くの情報を入力し、迅速な判断を 求められる競技であり、視機能と反応時間は競技力の優劣を決 定する重要な因子である。そこで高校男子卓球選手を対象に競 技特性である視機能と全身反応時間（神経伝導時間,筋収縮時 間）の測定を実施し、競技レベルにより視機能と全身反応時間 に差異があるのかについて検討した。【方法】対象者は高校男 子卓球選手全国大会出場者A群：23名（16.3 00.9 歳,競技歴8.5 2.0 年、非出場者B群: 22 名 $(16.4 \pm 0.9$ 歳,競技歴7.6 2 2.5年) である。 対象者はプレーをしている矯正状態での視機能を測定した。対 照群は一般男子学生129名の測定者の中から過去に運動習慣が 無い男子学生NA群：11名（19.4 土1.3歳）を抽出した。各群と も静止視力 1.0 以上を対象とした。測定項目は (1) 静止視力 (2) KVA動体視力 (3) DVA動体視力 (4) コントラスト感度 (5) 眼球 運動 (6) 深視力 (7) 瞬間視力 (8) 眼と手の協応動作の8項目であ る。各測定結果の評価はスポーツビジョン評価基準に基づいて 5段階評価で行った。【結果】A群のKVA動体視力, 深視力はB 群より、静止視力, KVA動体視力, コントラストはNA群より有 意に優れた值であった。A群の合計得点はB群, NA群より有意 に優れた值であった。A群の全身反応時間,筋収縮時間はB群よ り有意に優れた值であった。さらに合計得点を従属変数、各測 定項目を独立変数とし、ステップワイズの重回帰分析を行い貢 献度について検討した。A群の競技力に関連性のある測定項目 は、OMS, DP, E/H, CS, KVA, VRT、B群はOMS, VRT, E/H, KVA, CS, DVA, DP, SVAの順あった。【結論】高校男子卓球選 手の競技力に優れた選手群はKVA動体視力,深視力、全身反応 時間では筋収縮時間が優れていることが示唆された。

Keywords : 高校男子卓球選手 視機能 反応時間
442. セット間の静的ストレッチングが伸長部位の筋酸素飽和 度および筋持久性パフォーマンスに及ぼす効果

○永澤 健 ${ }^{1}$ 、白石 聖 ${ }^{2}{ }^{1}$ 広島工業大学、 ${ }^{2}$ 了徳寺大学 $)$

【目的】スタティックストレッチング(SST)がもたらす生理学 的効果として血液循環の立進が知られており，SSTが筋疲労か らの回復を促進させることを説明する生理学的根拠になってい る。本研究では，セット間のSSTの実施が伸長部位の血液循環 に及ぼす効果について検討するとともに，筋疲労からの回復促 進にSSTが有効であるか否かについて検討した。【方法】健常 成人男性 10 名を対象に，リストカール (50\%1RM) を5分間の 休息を挟み $2 セ ッ ト$ 実施した。 セット間に手関節伸展の受動的 SST（最大伸展角度, 伸長時間 30 秒, 反復回数3回）を実施した, リストカールは1セット目を30回（運動時間1分間），2セット目 を疲労困諅まで行い, この挙上回数から筋持久性パフォーマン スを評価した。セット間のSSTを実施しないコントロール条件 を設定した。前腕屈筋群の筋酸素飽和度 $\left(\mathrm{StO}_{2}\right)$ は近赤外分光法 により測定した、【結果】セット間のSST実施によって，2セッ 卜目の運動開始前の $\mathrm{StO}_{2}$ は，コントロール条件よりも平均 $3 \%$ 上昇した $(\mathrm{p}<0.01)$. SST条件の筋持久性パフォーマンス $(28.3$ 土4.9回）は，コントロール条件（33.9 27.5 回）と比較して有 意な低下を示した $(\mathrm{p}<0.05)$.【考察】セット間のSSTの実施は $\mathrm{StO}_{2}$ を上昇させたことから, SSTにより筋血流量が増大したも のと考えられた。一方，セット間のSSTは直後に行う運動の筋 持久性パフォーマンスを一過性に低下させることが示された。 したがって，筋疲労の回復促進を目的としてセット間にSSTを 実践するときに，筋の血液循環の立進には効果が得られるもの の, 筋疲労からの回復促進という点に関しては注意が必要であ ると考えられた。【結論】セット間のSST（伸長時間 30 秒 $\times 3$ 回） の実施は，伸長部位の筋血流量を増加させて $\mathrm{StO}_{2}$ を上昇させる 効果があること, 一方, 直後に行う運動の筋持久性パフォーマ ンスの回復促進に有効でないことが示された.

Keywords：ストレッチング 筋酸素飽和度 近赤外分光法

\section{5 分間の静的ストレッチング直後の筋力低下は10分以内} に戻る

○水野 貴正 ${ }^{1}$ 、伊藤 紗和 ${ }^{1}$ 、松本 彩 ${ }^{1} 、$ 松本 実 ${ }^{1}$ 梅村 義 久 ${ }^{1}$ ('京大学大学院 運動生理学研究室)

【背景】静的ストレッチングがその後の発揮筋力を低下させる ことは数多く報告されている。この筋力低下の原因として、筋 腱複合体の粘弾特性の変化の貢献が大きいと考えられている。 一方で、5分間の静的ストレッチングによる筋腱複合体の粘弾 特性の変化は10分以内に回復することが報告されている。【目 的】本研究の目的は、5分間の静的ストレッチングによる等尺 性筋力の低下がどれくらい持続するのか明らかにすることとし た。【方法】被験者は女子学生19名であった。被験者は足関節 の等尺性随意最大底屈筋力測定を行い、その後5分間の静的ス トレッチングまたは5分間の仰臥位安静を行った。ストレッチ ングまたは安静直後、および5分、10分、15分、30分後に再び 足関節の等尺性随意最大底屈筋力測定を行った。静的ストレッ チングは、被験者が下腿部に痛みを生ずることなく最も伸びて いると感じる角度で足関節を1分間保持するという手技を5回繰 り返した。【結果】足関節の等尺性随意最大底屈筋力は、安静 試行においてpreと比較して有意な変化はなかった。しかしな がら、静的ストレッチング試行ではストレッチング直後にpre と比較して有意に低下し、この低下は5分後まで持続したが 10 分以内に回復した。【結論】5分間の静的ストレッチングにより 等尺性随意最大底屈筋力は低下するが、10分以内に回復する。

Keywords : 静的ストレッチング 底屈筋力 効果持続時間 